\title{
FEMININITAS GEISHA DALAM NOVEL ARTHUR GOLDEN MEMOIRS OF A GEISHA
}

\author{
Oleh: Mundi Rahayu \\ Fakultas Humaniora dan Budaya UIN MMI Malang \\ 085229922018
}

\begin{abstract}
Geisha is an entertaining artist in Japan during Edo period (1603-1868) when cities were growing up and wealthy spread out among merchant class. The wealthy was followed by the building of teathers, restaurants, clothes and several entertaining places. Then, the identity of womanship for a geisha can be easily recognized through her beautiful and elegant performance. This sort of performance which makes geisha is different from other commercial worker women. Her feminity is also shown by her ability to entertain original japanese society that is her ability to play japanese traditional music tools such as drum and shamisen. She is also able to sing and dance. She has also the ability in dringking tea ceremony service. Geisha's feminity is relatively similar with women's feminity in common which is agreed by society. What makes them different is that geisha's feminity is developed professionally and is made as survival way and even as an access to get into broader economics and politics. Ironically, to some extent, that brings a risk for a geisha due to her position as a client for her patronage.
\end{abstract}

\section{A. Pendahuluan}

Geisha dan budaya Jepang menjadi popular dalam dunia budaya pop kontemporer terutama semenjak kesuksesan Arthur Golden dengan bukunya Memoirs of a Geisha yang terbit tahun 1997, yang kemudian diiringi dengan kesuksesan filmnya dengan judul yang sama. Sebelum Arthur Golden, sudah ada beberapa buku mengenai Geisha, yang kesemuanya berkontribusi pada kepopuleran geisha dalam budaya pop kontemporer. Seiring dengan popularitasnya, ada banyak pertanyaan mengenai apa dan bagaimana geisha dalam konstelasi budaya Jepang.

Dengan dandanannya yang sangat unik dan menarik, para geisha ini menarik perhatian dunia. Geisha selalu mengenakan kimono yang warna dan coraknya tergantung pada musim dan acara yang dihadirinya, untuk mengenakannya harus dibantu oleh asisten dan membutuhkan waktu yang tidak sedikit. Dengan make-up putih tebal, dan berbagai ketrampilan verbal (menghibur dengan obrolan yang menarik) dan nonverbal (seni menghibur dengan berbagai permainan, bermain alat musik tradisional Jepang, seperti drum, suling, dan shamisen dengan sikap selalu anggun dan menarik ) yang dipelajarinya secara intensif selama bertahun-tahun, yang menjadi para geisha ini bisa dibedakan dengan para penghibur lain atau bahkan dengan para pekerja seks komersial.

Geisha adalah para seniman yang mendedikasikan diri dengan memenuhi standar kinerja tertinggi dalam menyanyi, menari dan bermain music tradisional dan mereka harus melakukan 
training yang keras sebelum melakukan debutnya sebagai seorang geisha. Biasanya seorang geisha melakukan penampilannya pada lingkup kecil, di hadapan seorang atau beberapa orang tamu di 'teahouse' sekaligus dengan memberikan hiburan melalui percakapan dan permainan menarik yang kesemua ketrampilan ini harus dipelajari terlebih dahulu.

Geisha muncul sebagai seniman penghibur di Jepang selama periode Edo (1603-1868) ketika kota-kota berkembang dan kemakmuran merebak di kalangan kelas pedagang, dan kemakmuran ini juga dialirkan untuk memperelok kota-kota tersebut dengan teater, restoran, pakaian, dan tempat-tempat hiburan.

Tempat-tempat hiburan seperti ini menawarkan bukan hanya hiburan tapi juga romansa, spontanitas, tampilan elegan. Tempat ini menawarkan akses ke rumah bordil juga, namun para laki-laki ke sana untuk minum, makan, mendengarkan musik, menulis puisi, menikmati hiburan, dan bersosialisasi. Di sinilah para geisha bekerja, juga dengan para pekerja seks komersial dan para penghibur lainnya yang diatur oleh pemerintah.

Pada awalnya, tahun 1600an, geisha dilakukan oleh para laki-laki yang menampilkan musik, dan hiburan pada pesta-pesta. Geisha perempuan baru muncul di pertengahan 1700an, dan kemunculan geisha perempuan jauh lebih menarik hati audiensnya sehingga sampai tahun 1780, geisha perempuan ini jumlahnya mendominasi.

\section{B. Memoirs of a Geisha}

Karya sastra merupakan refleksi dari keadaan sosial masyarakatnya. Novel ini memotret kehidupan geisha di distrik Gion, Jepang awal abad 20. Kehidupan geisha di awal abad duapuluh ditampilkan dengan sangat detail dalam novel ini, mulai bagaimana seorang anak kecil dari keluarga miskin direkrut untuk dimasukkan ke Okiya, rumah untuk para geisha, sampai berbagai kebiasaan yang dilakukan seorang geisha sepanjang hidupnya sebagai geisha, serta bagaimana konsep femininitas seorang geisha muncul dan dibangun.

Novel ini dimulai dengan perjalanan hidup seorang anak kecil, Chiyo, yang berasal dari keluarga yang sangat miskin. Karena kemiskinannya, ayah Chiyopun mengijinkan ketika anaknya dibawa Tuan Ichiro Tanaka untuk dibawa ke rumah Okiya (rumah untuk para geisha), dengan harapan dia akan mendapatkan kehidupan yang lebih baik. Chiyo sendiri tidak tahu bahwa dia akan dibawa ke Okiya. Dia mengira bahwa dia akan diadopsi oleh Tanaka. Maka dimulailah perjalanan hidup Chiyo yang berusia 9 tahun, pada awalnya dengan kakaknya, Satsu, keluar dari kampungnya yang miskin dan masuk ke dunia gemerlap geisha, yang tidak terbayang sama sekali sebelumnya.

Bagi Chiyo kecil, dijual ke Okiya jelas merupakan awal neraka terbentang di hadapannya. Sebagai anak kecil dia sama sekali tidak membayangkan hidup di luar keluarganya yang tinggal di gubuk kecil (dengan ibunya yang sakit, dan ayahnya yang sudah tua). Kehidupan di rumah Okiya ini jauh dari kenyamanan dan impian anak kecil. Sebagai anak umur 9 tahunan yang baru datang, Chiyo menjalani perannya sebagai seorang pembantu rumah yang paling yunior. Kerasnya kehidupan di sini, sampai-sampai dia berniat untuk melarikan diri dengan naik ke atap rumah dan berjalan dari atap rumah satu ke atap rumah lainnya, di malam hari yang sangat dingin, dan berakhirlah dia dengan terjatuh dari atap sebuah rumah, dan diserahkan kembali ke Okiya tempat dia bernaung dan tentu saja diganjar dengan hukuman. 
Dari seorang anak kecil yang lugu ketika masuk ke Okiya mulailah seorang Chiyo mempelajari konsep 'menjadi perempuan'. Setelah beberapa tahun berada di Okiya Nitta ini, pemahaman menjadi perempuan semakin terbentuk dalam proses menjadi geisha, Chiyo mempelajari berbagai 'aturan' dan adat kebiasaan serta 'ritual'sebagai geisha. Beberapa tahun menjadi pembantu rumah tangga, Chiyo kemudian menjadi anak yang dididik menjadi geisha. Bertahun-tahun persiapan yang dilakukan sebelum seseorang menjadi geisha. Persiapan tersebut dilakukan dengan menempuh pendidikan ketrampilan sebagai calon geisha, serta 'magang' kepada geisha senior, serta menempuh berbagai ritual seperti upacara mengganti nama sebelum menjadi geisha penuh, mizuage (menjual keperawanan kepada penawar tertinggi) dan mendapatkan 'danna' (patron yang mempunyai hubungan financial dan loyalitas khusus). Dari proses panjang inilah Chiyo mempelajari femininitas geisha. Konsep femininitas geisha dibangun dari masyarakatnya, yakni nilai-nilai yang dibangun dan disebarluaskan di setiap Okiya, dan tempat para calon geisha mendapatkan ilmu pengetahuan. Oleh karenanya, dalam artikel ini akan dibahas bagaimana konsep femininitas seorang geisha itu dan bagaimana proses ini dipelajari dan dikembangkan seorang geisha.

\section{Femininitas}

Menurut Burke dan Stets (2001), femininitas dan maskulinitas merupakan identitas gender seseorang, yakni bagaimana seseorang melihat diri mereka sendiri sebagai maskulin atau feminine sehingga mereka akan memaknai bagaimana menjadi perempuan atau laki-laki. Feminitas ini berakar pada masyarakat, bukan pada biologis seseorang. Masyarakatlah yang menentukan bagaimana menjadi perempuan dan bagaimana menjadi laki-laki.

Lebih lanjut Burke menyatakan bahwa dalam perspektif sosial, identitas gender ini melibatkan semua makna yang diterapkan pada seseorang dengan basis identifikasi gender seseorang. Pemaknaan inilah yang akan mendorong munculnya perilaku-perilaku yang terkait dengan identitas gender seseorang.

Pemaknaan diri terkait dengan identitas gender seseorang terjadi sejak lahir dan terbentuk dalam situasi social ketika seseorang mulai berinteraksi dengan orang-orang lain seperti orang tua, teman, atau guru. Seperti apa menjadi perempuan atau menjadi laki-laki itu kita pelajari melalui konsep kultural yang ada disekitar kita, yang sampai kepada kita melalui berbagai lembaga seperti agama, pendidikan dan model yang ditiru (orang tua, misalnya).

Wacana femininitas mengajarkan kepada para perempuan secara langsung atau tidak langsung melalui teks, bagaimana menjadi perempuan. Teks itu bisa muncul dalam berbagai bentuk seperti iklan, ikon, film, etalase took, koran, majalah, maupun 'ajaran-ajaran' yang diyakini dan disosialisasikan di sekitar perempuan, yang kesemuanya memberikan 'ajaran' bagaimana menjadi perempuan cantik. Anne Cranny-Francis (2003) menyatakan bahwa femininitas sebagaimana maskulinitas merupakan suatu pengetahuan dan teknik yang mengorganisasikan struktur kecantikan dan relasi kekuasaan yang menyertainya.

Femininity, like masculinity, is a body of knowledge and techniques that organizes the structure of beauty and its power relations. It structures not only how we do things, it structures why we want to do them - it gives us our desires, and the means to (almost) achieve them (2003:198-199) 
Apa yang dikemukakan oleh Anne Cranny di atas mempertajam pengertian femininitas, yakni bukan hanya bagaimana menjadi perempuan menurut konsep yang telah disusun oleh masyarakat, namun juga memperjelas bahwa melalui femininitas inilah 'struktur kecantikan dan relasi kekuasaan terbentuk. Jadi femininitas bukan hanya menyatakan bagaimana perempuan melakukan sesuatu namun juga mengapa melakukannya.

Secara lebih praktis, ketika orang bertanya femininitas maka dengan mudah orang akan menunjuk hal-hal yang membedakan perempuan dari laki-laki, mulai dari penampilannya, cara berkomunikasi, perilakunya, dan sebagainya, yakni hal-hal yang kasat mata, yang secara umum diamini masyarakat sebagai pembeda antara laki-laki dan perempuan. Meskipun masyarakat atau kultur yang ada menentukan mana-mana yang menjadi ciri perempuan atau laki-laki dalam berpakaian, berdandan, gaya rambut, bahkan parfum, namun ada mekanisme 'self regulating', yakni setiap orang (menyepakati 'aturan' ini) mengatur dan memutuskan untuk 'proper look' (berpenampilan secara tepat). Mereka menjadi subyek yang mengontrol dan mengatur diri, sebagaimana dinyatakan oleh Anne Cranny-Francis (2003:198), "they become self controlling and self regulating subject." Oleh karena itu menarik untuk memahami konsep femininitas perempuan ini dari sisi subyek (perempuan), untuk lebih memahami dan lebih berempati terhadap perempuan antarras dan antarbudaya.

\section{Femininitas Geisha dalam Memoirs of a Geisha}

Novel Memoirs of a Geisha memfokuskan pada kehidupan seorang anak perempuan bernama Chiyo. Pencarian akan identitas dan makna hidup dengan menarik diceritakan dalam beberapa bab awal novel ini. Digambarkan dalam novel ini Chiyo menjalani kehidupan di desanya yang terpencil Yoroido, dalam kemiskinan. Chiyo ditemukan dan dianggap mempunyai prospek sebagai geisha oleh Mr. Tanaka. Dengan ijin ayahnya, yang sangat miskin dan sakit-sakitan, dia dan kakaknya dibeli lalu dijual ke Nitta Okiya, rumah geisha. Tentu saja Chiyo kecil, dan Satsu kakaknya tidak tahu sebelumnya bahwa mereka akan dijual ke Okiya. Mereka mengira bahwa mereka akan diadopsi oleh Tuan Tanaka. Okiya dengan kehidupan geisha tidak pernah pula terbersit dalam pikiran anak-anak perempuan desa itu.

Di Okiya Nitta inilah Chiyo menjalani babak baru kehidupannya. Sebagai pendatang baru ia mendapatkan peran pertama sebagai pembantu rumah tangga. Di Okiya Nitta ini dia cepat mempelajari berbagai hal tentang geisha. Di Okiya ini ada yang menjadi pimpinan tertinggi, pemilik rumah tersebut yakni yang disebut dengan ibu, nenek dan bibi. Setiap gadis kecil yang datang pertama kali ke okiya pasti posisi pertamanya adalah menjadi pembantu rumah tangga, dan mengantikan orang yang terlebih dulu ada di situ sebelumnya . Chiyo menggantikan gadis kecil sebaya dengannya, yang posisinya sebagai pembantu sambil menunggu saatnya training geisha. Gadis ini dia beri julukan Pumpkin. Sedangkan satu-satunya geisha yang tinggal di okiya tersebut adalah Hatsumomo, seorang geisha yang lumayan popular di distrik Gion.

Seorang geisha selalu berpenampilan di atas rata-rata. Kimono yang dikenakannya selalu yang terbaik. Kimono merupakan pakaian khas tradisional Jepang, yang dikenakan para wanita dengan berbagai pola dan corak serta warna. Kerumitan pembuatan kimono, yang memakan waktu dua sampai tiga tahun karena harus melukis corak dan menyulamnya menampilkan keindahan dan seni yang dibanggakan orang Jepang. Seorang geisha akan mengenakan kimono 
dengan warna dan corak yang berbeda sesuai dengan musim atau sesuai dengan acara yang mereka hadiri. Berikut ini kekaguman yang ditunjukkan Chiyo ketika melihat Hatsumomo, geisha yang tinggal di Nitta Okiya.

There on the step of the entryway, just slipping her feet into her lacquered zori, stood an exquisitely beautiful woman wearing a kimono lovelier than anything I'd ever imagined. I'd been impressed with the kimono worn by the young bucktoothed geisha in Mr. Tanaka's village of Senzuru; but this one was a water blue, with swirling lines in ivory to mimic the current in a stream. Glistening silver trout tumbled in the current, and the surface of the water was ringed with gold wherever the soft green leaves of a tree touched it. I had no doubt the gown was woven of pure silk, and so was the obi, embroidered in pale greens and yellows. And her clothing wasn't the only extraordinary thing about her; (p.21 par 5)

Kimono, dengan demikian merupakan salah satu ciri femininitas seorang geisha. Ketika keluar rumah, seorang geisha selalu menampilkan kimono yang bagus. Bahkan, megah tidaknya kimono yang dikenakannya akan mempengaruhi penilaian dan gengsinya sebagai seorang geisha.

Geisha Nitta Okiya, Hatsumomo, selalu mengenakan kimono-kimono terbagus. Kimono tersebut milik okiya. Rumah yang disebut Okiya itu mempunyai satu ruangan yang berisi properti terutama baju-baju kimono lengkap dengan obinya yang bagus, berwarna-warni dan berharga mahal. Harta milik okiya yang berupa kimono -kimono bagus dan mewah tersebut menunjukkan kekayaan okiya. Sebagaimana perusahaan, seorang geisha adalah mesin pencari uang. Oleh karenanya, mesin pencari uang ini harus dijaga baik-baik oleh manajemen okiya agar tetap bisa menjalankan roda bisnis dengan lancar.

Penampilan geisha Hatsumomo sedemikian memesona Chiyo kecil. Dari sinilah konsep identitas gender geisha mulai terbangun, yakni bahwa seorang geisha tidak akan berpenampilan alakadarnya. Seorang geisha akan menampilkan diri secara maksimal untuk menegaskan femininitasnya, yakni anggun, cantik, dan berkelas. Tidak hanya pakaiannya saja, tapi juga cara berdandan seorang geisha. Penampilan mulai dari pakaian, sanggul rambut, riasan wajah, serta segala asesori yang melekat pada seorang geisha merupakan femininitas geisha, yang dilestarikan dan dikembangkan di kalangan geisha.

Menjadi seorang geisha tidaklah selalu harus cantik. Namun dengan ketrampilan yang dipelajarinya dan dengan teknologi kecantikan yang didapatkannya seorang geisha bisa menjadi seorang geisha yang sangat cantik yang akan membuat orang (laki-laki) terpesona dan tidak akan keberatan untuk mengeluarkan hartanya untuk seorang geisha. Seorang geisha, sebenarnya adalah seorang penghibur yang menggunakan seni tradisional dalam menjalankan profesinya. Bukan hanya seni tradisional, seorang geisha juga harus mempelajari penampilan tradisionalnya yang cukup rumit.

Mempelajari dan memahami femininitas geisha ini dilakukan dalam waktu yang lama. Dalam novel ini Chiyo yang berumur 9 tahun, masuk ke Okiya Nitta pertama kali diberi pekerjaan sebagai pembantu atau istilah populernya "shikomi". Mereka diharuskan mengerjakan 
apapun yang diperintahkan. Tahapan shikomi ini sebenarnya juga merupakan tahap awal pendidikan untuk memahami femininitas geisha. Sebagai seorang shikomi, Chiyo harus mengerjakan semua pekerjaan rumah yang diberikan kepadanya, tanpa bisa menolak. Sebagaimana dikatakan oleh "Auntie", "It's an okiya. It's where geisha live. If you work very hard, you'll grow up to be a geisha yourself. But you won't make it as far as next week unless you listen to me very closely" (24).

Selain itu, dia juga diberi tugas untuk menunggu kedatangan geisha senior di okiya, yang biasanya pulang larut malam, bahkan sampai jam 2 atau tiga dini hari. Setelah menunggu kedatangan geisha, Chiyo membantunya melepaskan pakaian kimononya yang berlapis-lapis dan mempersiapkan tempat tidur geisha.

Di tahap menjadi shikomi ini, Chiyo bukan hanya menjadi pembantu rumah tangga, namun dia juga mempelajari bagaimana seorang geisha menjadikan dirinya cantik, dan shikomi juga mempelajari berbagai tradisi geisha termasuk gaya berpakaian dan dandanan geisha, serta berbagai asesoris yang melengkapi riasan sanggul rambutnya. Dengan kata lain, semua femininitas geisha dipelajari sampai detail mulai tahap menjadi shikomi ini. Shikomi akan tahu persis gaya hidup seorang geisha dan berbagai tradisi yang melekat pada seorang geisha.

Salah satu hal utama bagi geisha adalah merias diri. Merias dengan berbagai aksesorisnya mempertegas femininitas geisha. Riasan tradisional seorang geisha itu khas, dengan bedak atau cat warna putih, dengan member lipstick merah pada bibir bawah dan bibir atas dibiarkan tanpa lipstick. Dandanan gaya rambut seorang geisha sangat rumit dan seringkali dipakai tidak hanya satu hari saja.

her face was painted a kind of rich white, like the wall of a cloud when lit by the sun. Her hair, fashioned into lobes, gleamed as darkly as lacquer, and was decorated with ornaments carved out of amber, and with a bar from which tiny silver strips dangled, shimmering as she moved. ...I was so startled by her appearance

Seorang geisha akan mulai berdandan dengan mengecat wajahnya dengan bedak putih merata di seluruh muka dan leher, termasuk leher bagian belakang (tengkuk) sampai ke punggung. Pakaian kimono yang dikenakan seorang geisha selalu ber"leher" rendah di bagian tengkuk sampai agak ke punggung. Ini tak lain untuk menunjukkan sensualitas pemakainya. Dengan demikian, pakaian kimono yang tertutup dan berlapis, tidak menghilangkan sensualitas sebagai salah satu ciri femininitas geisha.

Geisha seringkali dikelirukan dengan pekerja seks komersial. Profesi sebenarnya seorang geisha adalah penghibur, yakni menghibur para tamu di 'tea house' dengan memainkan alat music tradisional, membaca puisi, atau sekedar menemani dengan obrolan dan lelucon ringan yang menghibur, tidak termasuk hubungan seksual. Salah satu ciri yang membedakan geisha dengan seorang pekerja seks komersial adalah cara memakai obi. Geisha mengikat obi di belakang sedangkan 'oiran' mengikat obi di depan. Hal ini diberikan contoh dalam novel ini, ketika Chiyo mencari kakaknya, Satsu, yang ternyata menjadi pekerja seks komersial di daerah yang agak jauh dari okiya Nitta. Dia mendapati Satsu dengan kimono berwarna kuning merah dan obi diikatkan di depan. Ikatan obi di depan ini menandakan bahwa dia adalah seorang 'prostitute', pekerja seks komersial. 
Her skin looked pale, almost gray-though perhaps it was only because she wore a kimono of garish yellows and reds. And her mouth was painted with a bright lipstick like the kind Mother wore. She was just tying her sash in the front, like the women I'd seen on my way there.(53)

Gaya hidup geisha yang terkesan glamor, dari cara berdandan dan berpakaian, ternyata juga dilingkupi dengan tradisi dan mitos. Setelah berjam-jam berdandan dengan dibantu oleh peñata busana dan periasnya, sebelum melangkah keluar dari okiya, seorang geisha menjalani ritual kecil, sebagaimana digambarkan dalam novel ini. Hatsumomo, geisha di okiya Nitta, selesai berdandan dan mempersiapkan diri untuk pergi dari okiya untuk bekerja, melakukan ritual kecil.

She took from it something that looked to me like a piece of flint, along with a rectangular stone like the kind fishermen use to sharpen their knives, and then stood behind Hatsumomo and struck the flint against the stone, causing a little cluster of sparks to jump onto Hatsumomo's back. I didn't understand this at all; but you see, geisha are more superstitious even than fishermen. A geisha will never go out for the evening until someone has sparked a flint on her back for good luck. (22)

Ritual kecil yang dilakukan yakni, seseorang memantik batu api di punggungnya, sebagai tanda untuk keberuntungan.

Femininitas seorang geisha juga menuntutnya untuk tampil anggun mulai dia melangkahkan kakinya keluar okiya. Cara dia berjalan dengan kimono yang membelit dari atas ke bawah, tetap akan memperlihatkan femininitas seorang geisha yang anggun, berjalan dengan 'floating away' dengan ujung kain kimononya sedikit melambai anggun.

Hatsumomo walked away, using such tiny steps that she seemed to glide along with the bottom of her kimono fluttering just a bit. I didn't know that she was a geisha at the time, for she was worlds above the creature I'd seen in Senzuru a few weeks earlier. I decided she must be some sort of stage performer. We all watched her float away...(22)

Sebagai tambang 'emas' seorang geisha akan di manjakan dan semua orang di okiya akan berpikir keras untuk meningkatkan performa geisha, sehingga dia akan sukses sebagai seorang geisha dan akan memberikan pendapatan bagi okiya.

We all of us think of only one thing how we can help Hatsumomo be successful as a geisha. Even Granny. She may seem like a difficult old woman to you, but really she spends her whole day thinking of ways to be helpful to Hatsumomo."(30)

Dalam menjalankan roda bisnis okiya ini, semua orang yang ada di okiya, semuanya perempuan, bekerja keras agar bisnis okiya dengan ujung tombak geisha, ini berjalan lancar. Pendapatan seorang geisha tidak dia terima langsung, melainkan diadministrasikan oleh seorang administrator daerah di distrik tersebut. Dari setiap kunjungan seorang geisha ke setiap 'tea house' dia mendapatkan bayaran yang akan di atur dan diakumulasikan dan disetorkan ke okiya di mana geisha tersebut bernaung. Karena pentingnya geisha, meskipun kadang berulah, seperti 
Hatsumomo, yang seringkali berbuat tidak baik atau kadang juga jahat terhadap Chiyo, selama dia masih menjadi ujung tombak di Okiya Nitta, dia akan tetap didukung dan difasilitasi segala keinginannya.

Dalam tahapan menjadi shikomi, Chiyo mempelajari banyak hal, yang semuanya terkait dengan femininitas seorang geisha, yakni bagaimana menjadi perempuan dengan nilai-nilai femininitas yang telah ditetapkan oleh lingkungannya. Sebagaimana ditegaskan oleh Granny, bahwa cantik itu tidaklah terlalu penting, untuk bisa tampil cantik, anggun, dan berkelas, seorang gadis itu harus pintar sehingga dia mampu menjalani 'tranining' yang keras untuk menuju seorang geisha. Sebagaimana ditegaskan oleh Mother, salah satu orang yang paling berkuasa di okiya Nitta,

"Well, little girl," Mother told me, "you're in Kyoto now. You'll learn to behave or get a beating. And it's Granny gives the beatings around here, so you'll be sorry. My advice to you is: work very hard, and never leave the okiya without permission. Do as you're told; don't be too much trouble; and you might begin learning the arts of a geisha two or three months from now. I didn't bring you here to be a maid. I'll throw you out, if it comes to that."(26)

Dengan bekerja keras, mematuhi semua yang diperintahkan, sekitar satu bulan setelah berada di okiya Nitta, Chiyo mulai bersekolah, di sekolah geisha.di sekolah ini dia mempelajari segala hal berkait dengan femininitas geisha. Geisha adalah seorang penghibur, dengan ketrampilan utama bermain musik tradisional dan percakapan atau obrolan ringan, lucu yang membuat pendengarnya senang. Untuk itu Chiyo dan Pumpkim harus pagi-pagi datang ke sekolah geisha ini. Ada berbagai mata pelajaran yang harus ditempuh, seperti kelas music, menari, upacara minum teh. Semua anak perempuan yang ingin menjadi geisha harus masuk ke sekolah ini.

Kesibukan Chiyo pun bertambah. Selain harus pergi ke sekolah, dia juga didaftarkan ke "kantor registrasi" yang ada di daerah tersebut, untuk didaftarkan sebagai 'calon geisha'. Kantor inilah yang akan mendokumentasikan aktivitas professional seorang geisha, sekaligus menghitung pendapatan geisha, dan mengambil pajak dari pendapatan tersebut. Setiap sore, Chiyo harus memperhatikan baik-baik bagaimana Hatsumomo merias diri dan mengenakan kimono. Hal ini sudah menjadi tradisi bagi gadis yang masih dalam masa training untuk mengamati dan memperhatikan baik-baik geisha senior.

Memasuki masa training di sekolah geisha bukanlah hal sederhana. Para gadis kecil ini harus disiplin, tetap bekerja secara fisik, dan yang paling junior harus tidur larut malam menunggu sampai geisha pulang dan membantunya sampai si geisha tidur. Kerasnya training formal dan non formal ini harus dijalani mereka yang ingin menjadi geisha. Pumpkin, teman Chiyo di okiya Nitta, harus benar-benar berusaha sekuat tenaga untuk bisa memahami semua training, demi impian menjadi geisha.

I'd seen Pumpkin scramble out of the okiya every morning so early her eyes were still crusty; and she often seemed on the point of tears when she left. In fact, when she clopped past the kitchen window in her wooden shoes, I sometimes thought I could hear her crying. 
She hadn't taken to her lessons well-not well at all, as a matter of fact. She'd arrived in the okiya nearly six months before me, but she'd only begun attending the school a week or so after my arrival. Most days when she came back around noon, she hid straightaway in the maids' quarters so no one would see her upset.The following morning I awoke even earlier than(31)

Menjadi geisha merupakan satu-satunya tujuan hidup Pumpkin, karena dia tidak punya pilihan lain. Hal ini berbeda dengan Chiyo. Chiyo menganggap kesempatan untuk pergi ke sekolah geisha adalah kesempatan yang ditunggu dengan harapan bisa bertemu Satsu, kakaknya. Sayangnya, Pumkin tidaklah terlalu pintar untuk semua pelajaran yang diberikan di sekolah tersebut. Pumkin menyadari bahwa dia tidaklah pintar, oleh karenanya okiya dan sekolah geisha merupakan tempat yang tepat untuk masa depannya, dan apapun yang terjadi dia tidak akan menyia-nyiakan kesempatan untuk menjadi geisha.

"My uncle was a very nice man," she said. "Here's the last thing I heard him say before he sent me away. 'Some girls are smart and some girls are stupid,' he told me. 'You're a nice girl, but you're one of the stupid ones. You won't make it on your own in the world. I'm sending you to a place where people will tell you what to do. Do what they say, and you'll always be taken care of.' So if you want to go out on your own, Chiyo-chan, you go. But me, I've found a place to spend my life. I'll work as hard as I have to so they don't send me away. But I'd sooner throw myself off a cliff than spoil my chances to be a geisha like Hatsumomo." (32)

Bagi sebagian perempuan di Jepang, di awal abad 20 (novel ini mengambil setting Jepang tahun 1929), ketika ekonomi negara itu cukup bagus, menjadi geisha merupakan peluang untuk meningkatkan taraf hidup, bahkan sebagian mampu mendapatkan akses untuk masuk ke dunia bisnis atau masuk di kalangan atas, terutama ketika seorang geisha mampu mendapatkan "danna" (patron yang memberikan fasilitas keuangan yang lebih dari cukup untuk seorang geisha dan okiya tempat dia bernaung, dengan imbalan loyalitas tinggi dari sanga geisha) yang cukup kaya.

When she'd finished applying blush, she still had no eyebrows or lips. But for the moment she left her face like a bizarre white mask and asked Auntie to paint the back of her neck. I must tell you something about necks in Japan, if you don't know it; namely, that Japanese men, as a rule, feel about a woman's neck and throat the same way that men in the West might feel about a woman's legs. This is why geisha wear the collars of their kimono so low in the back that the first few bumps of the spine are visible; I suppose it's like a woman in Paris wearing a short skirt. Auntie painted onto the back of Hatsumomo's neck a design called sanbon-ashi-"three legs." It makes a very dramatic picture, for you feel as if you're looking at the bare skin of the neck through little tapering points of a white fence. It was years before I understood the erotic effect it has on men (39).

Periode training penting yang kedua adalah ketika seorang gadis diangkat menjadi 'adik' seorang geisha senior. Pumpkin telah diangkat menjadi adik Hatsumomo. Setelah beberapa waktu kemudian, Mameha mengajukan diri untuk menjadi saudara tua (kakak) bagi Chiyo. 
Setelah melalui serangkaian negosiasi secara financial, akhirnya Mother menyetujui Chiyo untuk diangkat adik oleh Mameha. Di usia 12 tahun, Chiyo menjadi "novice" geisha. Periode ini sangat penting, sehingga perlu upacara khusus untuk mendeklarasikan pengangkatan 'kakak beradik' ini. Juga, Chiyo mempunyai nama baru yang diberikan oleh Mameha, setelah berkonsultasi dengan ahlinya. Nama baru Chiyo adalah Sayuri. Pelantikan sebagai "novice" dengan nama baru ini dideklarasikan dalam upacara, yang dihadiri oleh orang terdekat. Setelah upacara sederhana ini, maka babak baru perjalanan calon geisha pun dimulai.

The ceremony, which was attended by the mistress of the Ichiriki, lasted only about ten minutes. A maid brought a tray with several sake cups, and Mameha and I drank together. I took three sips from a cup, and then passed it to her and she took three sips. We did this with three different cups, and then it was over. From that moment on, I was no longer known as Chiyo. I was the novice geisha Sayuri. During the first month of apprenticeship, a young geisha is known as a "novice" and cannot perform dances or entertain on her own without her older sister, and in fact does little besides watching and learning.(108)

Selain upacara menjadi "adik" geisha senior, seorang "novice" harus lebih banyak belajar dan mengamati hal-hal yang dilakukan seniornya. Selama bulan pertama magang, dia tidak boleh menari atau menampilkan hiburan tanpa 'kakak' seniornya. Selama menjadi "adik" inilah Chiyo mempelajari berbagai hal teknis langsung di lapangan, selain datang ke sekolah geisha di mana dia mempelajari berbagai cara memainkan alat musik tradisional Jepang (drum, seruling, shamisen), menari dan bernyanyi, serta kelas "tea-ceremony". Upacara minum teh ini bukan sekedar minum teh bersama, namun lebih sebagai tradisi dengan berbagai tata cara yang mesti dipelajari untuk bisa menyajikannya dengan baik. Seorang geisha harus bisa berperan dalam upacara minum teh ini, bahkan ini merupakan salah satu tugas pokoknya

Tea ceremony is a very important part of a geisha's training. It isn't unusual for a party at a private residence to begin with a brief tea ceremony. And the guests who come to see the seasonal dances in Gion are first served tea made by geisha.

My tea ceremony teacher was a young woman of perhaps twenty-five who wasn't a very good geisha, as I later learned; but she was so obsessed with tea ceremony that she taught it as if every movement was absolutely holy. Because of her enthusiasm I quickly learned to respect her teaching, and I must say it was the perfect lesson to have at the end of a long morning. The atmosphere was so serene. Even now, I find tea ceremony as enjoyable as a good night's sleep(94)

Untuk memperkenalkan 'adik' ini, sang kakak, Mameha membawa Chiyo setiap kali dia pergi, untuk diperkenalkan ke para klien, "patron" dan orang-orang penting, serta ke berbagai 'teahouse' dan juga ke berbagai acara pesta-pesta klien Mameha.

Berbagai hal teknis yang dipelajari oleh Chiyo sebagai geisha magang adalah berbagai hal terkait dengan femininitas geisha. Misalnya, sang kakak, geisha yunior, memastikan bahwa si adik bisa mempelajari dengan tepat bagaimana mengekspresikan malu, tertawa ketika para laki-laki melemparkan lelucon yang mungkin agak menggoda. Seringkali pula si kakak 
menunjukkan cara dan rahasia bermake up yang tepat. Mameha juga merasa berkuajiban untuk memastikan bahwa si adik menarik perhatian orang-orang yang perlu dia kenal, seperti ke "teahouse", restauran-restauran penting, ke penata rias, penata busana yang sangat penting dalam kehidupan sehari-hari seorang geisha.

Pasangan "kakak-adik" ini merupakan hubungan yang penting bagi kedua belah pihak. Di satu sisi si adik mendapatkan pelajaran penting untuk mempersiapkan diri menjadi geisha, namun sang kakak juga harus bekerja keras dan bertanggungjawab untuk menjadikan si adik berhasil sebagai geisha. Secara financial, si kakak mendapatkan prosentasi dari penghasilan si "adik" (geisha magang). Seorang kakak akan menjadi orang yang paling menentukan nasib dan kecemerlangan karir si calon geisha baru. Meskipun sudah dipelajari di sekolah geisha, Mameha juga memberikan berbagai trik dan pelajaran berharga secara langsung kepada Sayuri, dalam berbagai hal, misalnya dalam upacara minum teh, Mameha memberitahukan bagaimana cara menuangkan teh dengan tetap menampilkan femininitasnya, yang memberikan daya pikat bagi para laki-laki.

So I drew my sleeve up above my elbow and held my arm out for her to see. She took it and turned it in her hands to look at the top and the bottom. "You have a lovely arm; and beautiful skin. You should make sure every man who sits near you sees it at least once." So I went on, pouring tea again and again, until Mameha felt satisfied that I drew my sleeve out of the way enough to show my arm without being too obvious what I was doing. I looked laughable if I hiked my sleeve up to my elbow; the trick was to act like I was merely pulling it out of the way, while at the same time drawing it a few fingerwidths above my wrist to give a view of my forearm. Mameha said the prettiest part of the arm was the underside, so I must always be sure to hold the teapot in such a way that the man saw the bottom of my arm rather than the top(109)

Yang diajarkan oleh Mameha bukan sekedar bagaimana membuat teh dan menuangkannya, tapi lebih pada teknik-teknik mengeksplotasi femininitas perempuan (geisha) dalam setiap detil tanpa terlalu terlihat secara mencolok. Ini adalah femininitas Timur, di mana perempuan dituntut untuk anggun, halus, tidak vulgar, namun menyodorkan daya tariknya sebagai perempuan. Dalam kasus ini femininitas perempuan yang dieksploitasi tidak menjadikan seorang geisha sekedar korban karena ada hubungan timbal balik yang saling menguntungkan.

Seorang 'novice' geisha juga dituntut menampilkan femininitasnya yakni tampil malumalu seperti kanak-kanak, sebagaimana dikatakan oleh Sayuri, "I wasn't supposed to drink sake, because an apprentice geisha- particularly one still in her novitiate-should appear childlike." dan tidak boleh minum sake (tidak boleh mabuk) dan secara umum seorang geisha tidak boleh mempunyai hubungan khusus dengan laki-laki atau mempunyai kekasih. Hal ini ditujukan untuk menjaga profesionalitasnya, walaupun lebih bermakna kapitalis, yakni kalau seorang geisha mempunyai kekasih maka nilainya sebagai komoditas akan hancur, dia tidak akan disukai oleh para laki-laki kliennya.

Permasalahan yang sering diperdebatkan pada tradisi geisha adalah ritual "mizuage", yaitu menjual keperawanan dengan tawaran tertinggi. Banyak yang berpendapat bahwa kebiasaan ini berarti mengkomoditaskan perempuan. Menganggap perempuan sebagai obyek untuk dijual, segala sesuatu dari perempuan dihargai dengan uang. Perempuan akan melakukan 
apa saja dalam upaya untuk bisa menjual apapun dari dirinya, meskipun kadang berisiko bagi perempuan itu sendiri.

Keperawanan merupakan hal yang sangat penting bagi perempuan terutama dalam budaya Timur. Di berbagai tempat dan budaya, keperawanan perempuan adalah satu keharusan, dan sama dengan kesucian, oleh karenanya harus benar-benar dijaga. Banyak laki-laki dan masyarakat pada umumnya mempermasalahkan perempuan yang kehilangan keperawanannya sebelum menikah. Meskipun, masyarakat tidak akan mempermasalahkan laki-laki "masih perawan" atau tidak ketika menikah. Dengan demikian keperawanan ini merupakan femininitas perempuan yang masih dipegang kuat di banyak budaya.

Dalam budaya geisha, keperawanan ini benar-benar merupakan komoditas penting. Sehingga aturan bagi para geisha yang masih magang maupun geisha yang sudah senior adalah tidak menjalin hubungan dengan laki-laki kecuali dia itu adalah patron atau danna. Sebelum "mizuage" seorang geisha magang harus dengan sangat hati-hati menjaga diri dan keperawanannya. Kalau dia kehilangan keperawanannya maka dia tidak akan berharga dalam arti sesungguhnya. Sebagaimana pesan Mameha kepada Sayuri ketika dia akan berangkat ke pesta Baron di Hakone. "Keep in mind that an apprentice on the point of having her mizuage is like a meal served on the table. No man will wish to eat it, if he hears a suggestion that some other man has taken a bite." (168) Pesan Mameha ini benar-benar berarti bagi Sayuri, karena di Hakone, di rumah Baron yang besar dan sepi, Sayuri yang ketakutan hampir saja kehilangan keperawanannya. Dengan demikian "mizuage" bisa dimaknai sebagai saat geisha secara resmi melepaskan keperawanannya dengan imbalan yang sesuai.

Dalam konteks novel ini akan kita dapatkan kenyataan bahwa Sayuri dalam usianya ke15 disodorkan pilihan untuk melakukan "mizuage". Mameha menawarkan mizuage ini kepada Sayuri bukan semata-mata ingin mendapatkan uang dari bisnis menjual keperawanan ini. Mameha sendiri beberapa tahun sebelumnya juga mendapatkan tawaran tertinggi dalam sejarah mizuage di wilayah tersebut. Dalam konteks Sayuri, Mameha menganggap "mizuage" pada diri Sayuri mempunyai beberapa makna strategis. Pertama, dengan tawaran tertinggi maka nama Sayuri yang melejit sebagai geisha magang. Ketenaran ini akan membawa kepada keberuntungan berikutnya, yakni akan memudahkan Sayuri mendapatkan danna yang kaya sebagai patronnya. Kedua, yang penting di mata Mameha, dengan tawaran tinggi untuk mizuage ini, Sayuri akan diangkat anak oleh "Mother". Ini berarti akan memenangkan persaingan antara Mameha-Sayuri dan Hatsumomo-Pumpkin, dan sekaligus mempercepat pelunasan hutang Sayuri kepada "Mother" pemilik okiya Nitta.

"Mother" pemilik okiya Nitta, sebelumnya sudah merencanakan akan mengangkat Pumpkin sebagai anak. Namun demikian, Mameha tahu persis bahwa pertimbangan mother untuk mengangkat anak adalah semata-mata pertimbangan secara bisnis. Siapa yang lebih menguntungkan secara financial untuk okiya Nitta, maka dialah yang akan diangkat menjadi anak. Persaingan untuk diangkat anak ini muncul antara Sayuri yang dimentori oleh Mameha dan Pumpkin yang dimentori oleh Hatsumomo.

Maka dimulailah tawaran dari pihak-pihak yang menginginkan "mizuage" Sayuri. Awalnya pertarungan penawaran dilakukan oleh Nobu dan Dr Crab. Namun di akhir, yang muncul adalah Dr Crab dan Baron, dan penawaran tertinggi jatuh pada Dr. Crab dengan harga sangat tinggi, bahkan tertinggi. Sebagai bagian dari bisnis di kawasan geisha nilai penawaran untuk mizuage ini secara legal juga dicatat oleh administrator Negara,. 
Sebagaimana diperhitungkan oleh Mameha, keberhasilan mendapatkan penawar tertinggi untuk mizuage ini akan membawa dampak besar bagi Sayuri. Sayuri diadopsi anak oleh Mother Nitta, dan ini adalah kemenangan telak Mameha-Sayuri atas Hatsumomo-Pumpkin.

Sebagai anak Mother Nitta, Sayuri mendapatkan hak yang lebih besar dari Hatsumomo di okiya. Dengan demikian, mizuage ini tidak semata-mata menempatkan Sayuri sebagai komoditas, melainkan Sayuri dengan dibantu oleh Mameha yang pintar mampu mengendalikan dan memanfaatkan mizuage ini sebagai akses untuk kepentingan Sayuri yang lebih besar.

Kemampuan mendapatkan danna (patron kaya yang akan mendukung secara financial kepada geisha dengan imbalan pelayanan dan kesetiaan yang eksklusif, sampai menjadi mistress) juga menjadi hal penting yang menjadi target geisha. Laki-laki yang menjadi danna berarti dia mempunyai sumber keuangan yang kuat, biasanya para pebisnis, atau pejabat tinggi. Sebagai patron, posisi danna memberikan bargaining yang tidak tertolak oleh kliennya (geisha). Dalam hal ini, geisha tidak mempunyai posisi tawar terhadap patronnya. Sebagai contoh Mameha mempunyai danna yang bernama tuan Baron yang sangat kaya dan sekaligus otoriter. Mameha sampai harus melakukan aborsi karena tuan Baron tidak ingin mereka mempunyai anak dengan Mameha sebagai mistress, dan sebagai laki-laki bersuami tuan Baron tidak akan menikah dengan Mameha.

"Well," the Baron said at last. "I suppose I'd forgotten, now that you mention it ... We certainly can't have any little barons running around, now can we? But really, Mameha, I don't see why you couldn't have reminded me about this in private ..." (167)

Melihat penderitaan Mameha, Sayuri pun menjadi lebih berhati-hati terhadap Baron.

Penolakan Mameha untuk datang ke pestanya di Hakone, membuat Baron marah, dan memutuskan hubungannya sebagai danna Mameha.

Sementara itu, Mameha menyodorkan Nobu sebagai calon danna bagi Sayuri. Sayuri mengenal baik Nobu. Mereka berdua mempunyai hubungan sangat baik. Namun demikian, Sayuri memilih menolak Nobu sebagai danna, karena Sayuri sangat mencintai Chairman dan ingin dia yang menjadi danna. Secara diam-diam Sayuri sudah lama jatuh cinta dengan Chairman dan terobsesi dengannya. Namun, selama Nobu menginginkannya, maka tidaklah terbuka kemungkinan Chairman menjadi danna bagi Sayuri, karena Chairman adalah sahabat Nobu dan Chairman tidak akan mencederai persahabatan keduanya. Untuk menolak Nobu, Sayuri menyetujui Jenderal Tottori sebagai danna, yang ternyata cukup membantu di masa sulit sebelum Perang Dunia II. Namun demikian, seiring berjalannya waktu Jenderal Tottori sendiri menghadapi masa sulit yang tidak memungkinkannya menjadi danna lagi.

Kembali, Sayuri dihadapkan dengan tawaran Nobu untuk menjadi danna. Dengan berbagai upaya, akhirnya Nobu memutuskan untuk mengurungkan niatnya untuk menjadi danna bagi Sayuri. Akhirnya, Chairman pun mengajukan diri menjadi danna bagi Sayuri dan cerita geisha Sayuri menjadi cerita yang berakhir bahagia.

\section{E. Kesimpulan}

Femininitas atau identitas keperempuanan bagi seorang geisha sangatlah penting dalam hidup serta karirnya. Identitas keperempuanan seorang geisha secara gampang bisa dikenali dari penampilannya yang selalu cantik, anggun dan berkelas. Penampilannya inilah, bila dilihat secara lebih seksama, yang membedakannya dengan para perempuan pekerja seks komersial 
lainnya. Femininitas geisha juga ditunjukkan dari kemampuannya untuk menjadi penghibur tradisional masyarakat Jepang dalam arti yang sebenarnya, yakni kemampuannya untuk memainkan berbagai alat music tradisional Jepang seperti drum, seruling, shamisen, dan menyanyi serta menari, dan yang tidak kalah rumitnya adalah keahlian dalam upacara minum teh.

Femininitas geisha tersebut bukanlah hal yang begitu saja dipahami atau didapatkan oleh para gadis yang ingin menjadi geisha. Mereka harus bekerja keras untuk bisa mendapatkan ketrampilan ini. Kerja keras yang mereka mulai semenjak masih kecil dan berlansgung selama bertahun-tahun. Bahkan ketika sudah menjadi geisha, mereka juga masih ke sekolah geisha untuk terus mengasah keahliannya. Femininitas ini dipelajari dan dikembangkan di komunitas geisha yakni di okiya dan juga masyarakat sekelilingnya serta sekolah geisha. Para calon geisha mempelajarinya secara langsung maupun tidak langsung, semenjak menjadi shikomi, novice geisha magang yang masih baru, geisha magang, sampai mereka menjadi geisha penuh.

Keperawanan menjadi perhatian penting dalam dunia geisha, sedemikian rupa sehingga peraturan untuk menjaga keperawanan ini menjadi concern masyarakat. Saat mizuage adalah saat melepaskan keperawanan dengan harga tinggi, yang memberi imbalan sepadan bagi si geisha dan memberikan akses yang lebih luas untuk karirnya sebagai geisha ke depan.

Dengan segala keahliannya mengembangkan femininitasnya, seorang geisha akan mendapatkan danna, patron yang kaya yang akan mendanai kebutuhannya secara financial, dan sebagai imbalannya sang patron akan mendapatkan kesetiaan dan layanan eksklusif dari geisha. Layaknya hubungan patron-klien, hubungan atas-bawah, posisi geisha tidaklah dalam posisi tawar yang bagus. Tuan Baron, "danna" Mameha memberi contoh patron yang sangat otoriter yang berkuasa atas kliennya, Mameha. Di sisi lain, Sayuri berhasil mendapatkan cintanya, Chairman dan menjadikannya sebagai danna. Karena hubungannya lebih didasari oleh cinta, maka hubungan patron-klien antara Chairman dan Sayuri berjalan mulus, dan berakhir bahagia. Melalui danna inilah seringkali akses seorang geisha menjadi lebih luas, tergantung luasnya akses yang dimiliki sang patron dan kemampuan yang dimiliki oleh seorang geisha, serta hubungan keduanya.

Bisa dikatakan bahwa feminitas seorang geisha relative sama dengan femininitas perempuan pada umumnya yang diamini oleh masyarakat. Yang membedakannya adalah femininitas geisha dikembangkan secara professional dan dijadikan sebagai sarana untuk survive dan bahkan untuk mendapatkan akses (ekonomi atau politik) yang lebih luas, meskipun seringkali membawa risiko bagi geisha karena posisinya sebagai klien di hadapan patronnya. 


\section{DAFTAR PUSTAKA}

Anne Cranny- Francis et al. 2003. Gender Studies, Terms and Debates, Palgrave Mcmillan: p. 198-199

Betterton, Rosemary. 1987. Looking on: images of femininity in the visual arts and media, Taylor and Francis (Publsher)

Burke, J.Peter and Stets, Jan. E. Femininity/Masculinity.2001. Encyclopedia of Sociology (digital). Revised Edition. New York: Macmillan Reference USA's, p. 997-1005.

Coupland, Justine and Richard Gwyn (ed),2003. Discourse, the Body and Identity, New York: Palgrave Macmillan.

Golden, Arthur, 1997. Memoirs of a Geisha: A Novel. New York: Alfred A. Knopf 